University of Nebraska - Lincoln

DigitalCommons@University of Nebraska - Lincoln

2006

Development of a reference dose for the persistent congeners of weathered toxaphene based on in vivo and in vitro effects related to tumor promotion

Ted Simon

U.S.EPA, simonfam@dscga.com

Randall Manning

Georgia Environmental Protection Division

Follow this and additional works at: https://digitalcommons.unl.edu/usepapapers

Simon, Ted and Manning, Randall, "Development of a reference dose for the persistent congeners of weathered toxaphene based on in vivo and in vitro effects related to tumor promotion" (2006). U.S. Environmental Protection Agency Papers. 178.

https://digitalcommons.unl.edu/usepapapers/178

This Article is brought to you for free and open access by the U.S. Environmental Protection Agency at DigitalCommons@University of Nebraska - Lincoln. It has been accepted for inclusion in U.S. Environmental Protection Agency Papers by an authorized administrator of DigitalCommons@University of Nebraska - Lincoln. 


\title{
Development of a reference dose for the persistent congeners of weathered toxaphene based on in vivo and in vitro effects related to tumor promotion
}

\author{
Ted Simon ${ }^{\mathrm{a}, *}$, Randall Manning ${ }^{\mathrm{b}}$ \\ ${ }^{a}$ US EPA Region 4, 61 Forsyth St. SW, Atlanta, GA 30303, USA \\ ${ }^{\mathrm{b}}$ Georgia Environmental Protection Division, Athens, GA, USA
}

Received 28 September 2005

Available online 10 February 2006

\begin{abstract}
Toxaphene is a mixture of chlorinated camphenes and bornanes that was produced and used in the United States until 1982. 1.3 million tons of toxaphene have been released worldwide. "Technical" toxaphene (TT) consists of a mixture of up to 800 different chemicals, known as congeners. TT weathers in the environment by both biotic and abiotic processes. The human body burden of toxaphene consists of only five persistent congeners that are not metabolized; three of these occur in considerably greater amounts than the other two. Because of the rapid metabolism and excretion of the non-persistent congeners, the persistent congeners that make up the human body burden most likely play a role in eliciting any potential adverse effects. EPA's toxicity assessment for TT is based on the occurrence of liver cancer in rodents, and considerable doubt exists whether this assessment is applicable to weathered toxaphene (WT). Using experimental results from European Union scientists, a reference dose (RfD) was developed for WT based on the three most persistent congeners that comprise the human body burden. The critical effect chosen was tumor promotion and this endpoint is considered protective for other endpoints as well. Although RfDs are typically derived for non-carcinogenic effects, the endpoint of tumor promotion is appropriate for RfD development because the experimental data suggest a dose threshold. The RfD for weathered toxaphene represented by the sum of the three major persistent congeners $\left(\sum 3 \mathrm{PC}\right)$ is $2 \mathrm{E}-05 \mathrm{mg} / \mathrm{kg}$-day. To apply this reference dose to a particular WT mixture, information is needed regarding the percentage of $\sum 3 \mathrm{PC}$ in the mixture.
\end{abstract}

Published by Elsevier Inc.

Keywords: Toxaphene; Weathering; Organochlorine; Pesticide; Tumor promotion; Reference dose

\section{Introduction}

Toxaphene is a mixture of chlorinated camphenes and bornanes that was produced and used in the United States until 1982. Toxaphene has the distinction of being the most used pesticide in history with 1.3 million tons having been released worldwide. Technical toxaphene (TT) consists of a mixture of up to 800 different chemicals, known as congeners. Once in the environment, TT undergoes weathering by both biotic and abiotic processes and the number and iden-

\footnotetext{
${ }^{*}$ Corresponding author.

E-mail address: simonfam@dscga.com (T. Simon).
}

tity of the congeners in weathered toxaphene (WT) are different than those in TT. Hence, toxaphene has presented a significant challenge to analytical chemists (de Geus et al., 1999, 2000). In addition, WT appears to have toxicity characteristics that are different from TT.

There is a large and growing literature on the analysis, occurrence, and toxicity of WT (e.g., de Geus et al., 1999, 2000) Several nomenclature systems have evolved. Readers unfamiliar with toxaphene chemistry invariably find multiple names for the same chemical to be a confusing issue. Regarding human exposure to WT, there are three significant congeners. The structures and names of these three congeners are shown in Table 1. Enantiomeric chiral forms exist for many of the congeners. Some 
Table 1

Nomenclature and structure of the three persistent toxaphene congeners

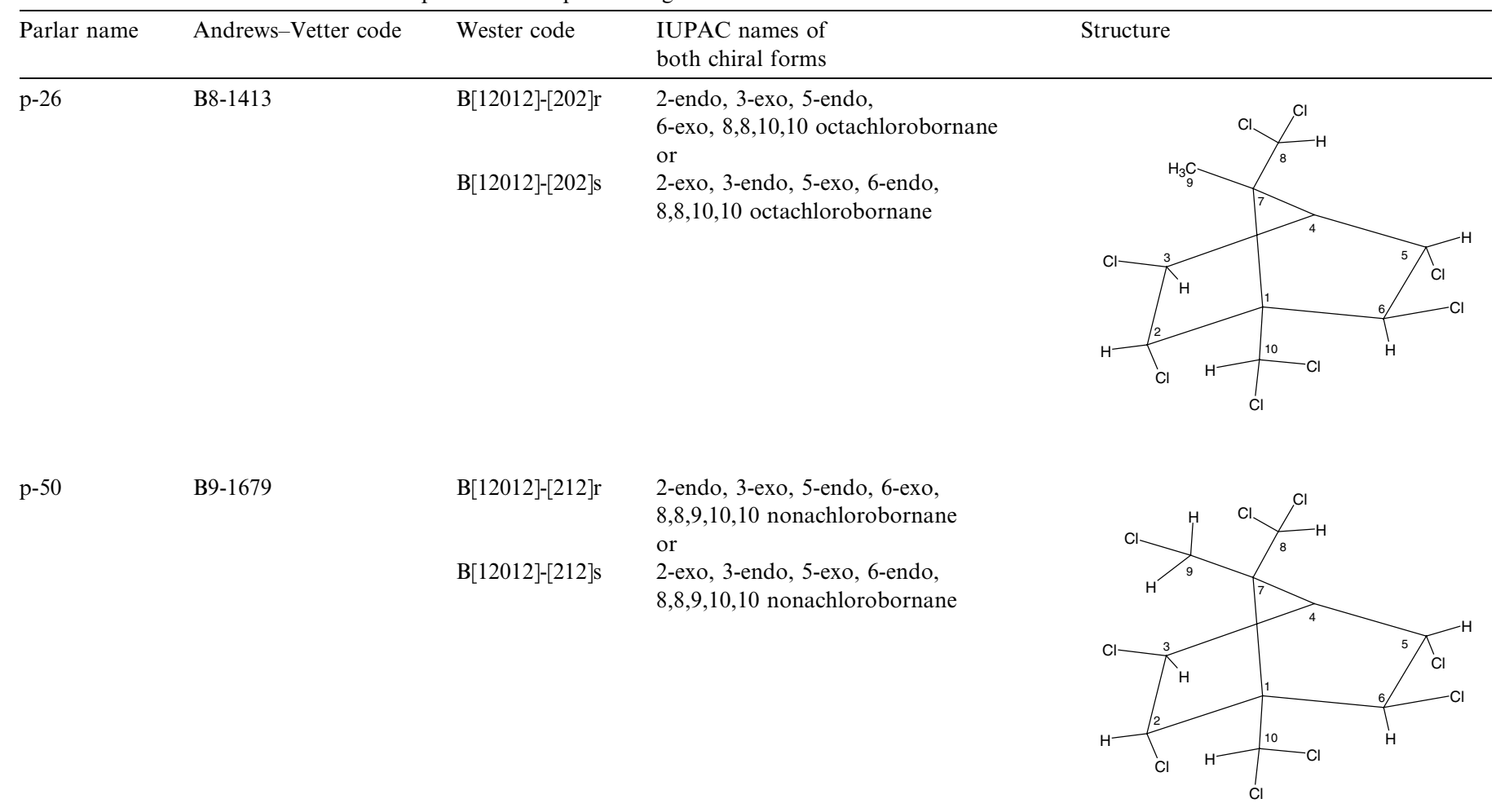

p-62 B9-1025 2,2,5,5,8,9,9,10,10 nonachlorobornane

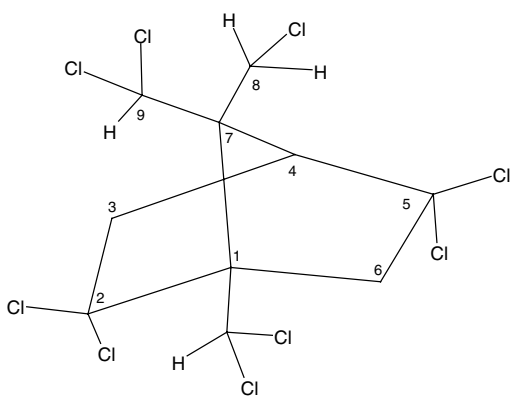

individual toxaphene congeners are also known as "Parlars" after Dr. H. Parlar, a pioneer of toxaphene analytical chemistry (e.g., Gill et al., 1996). Specific congeners have been given a Parlar number to easily refer to them (e.g., Parlar-26 or p-26). The major toxaphene congeners that persist in fish, marine mammals, human serum, and human breast milk are p-26, p-50, and p-62 (Table 1). The congeners $\mathrm{p}-23, \mathrm{p}-40, \mathrm{p}-41$, and $\mathrm{p}-44$ are also observed in lower amounts.

Regarding terminology in this paper, TT refers to the original technical toxaphene mixture; WT refers to the entire set of congeners remaining after TT has weathered in the environment; and, as defined in this paper, $\sum 3 \mathrm{PC}$ refers to the sum of the concentrations of $\mathrm{p}-26, \mathrm{p}-50$, and $\mathrm{p}-62$ occurring in either TT or WT.

\subsection{Cancer slope factors for technical toxaphene}

In 1991, EPA's IRIS program developed a cancer slope factor (CSF) for TT based on two rodent studies, the 1978 Litton Bionetics B6C3F1 mouse study and the 1979 NCI Osbourne-Mendel rat study that both administered technical toxaphene via feeding. The slope factor was derived using the linearized multistage model and had a value of 1.1 per mg/kg-day (e.g., Crump, 1984). In 2000, a peer review panel reevaluated the CSF for TT and recommended that the value be reduced to $0.1 \mathrm{per} \mathrm{mg} / \mathrm{kg}$-day (Goodman et al., 2000). The basis of this recommendation was a reexamination of the original histological materials by an expert pathology working group and application of benchmark dose modeling to account for high background liver tumor rates. In 2003, CAL-EPA (OEHHA, 2003) 
determined a CSF for TT based on the NCI and Litton Bionetics rodent studies. The value of the slope factor was 1.2 per $\mathrm{mg} / \mathrm{kg}$-day, essentially the same as the 1991 EPA slope factor. In 2004, Buranatrevedh (2004) derived a CSF of 0.86 per $\mathrm{mg} / \mathrm{kg}$-day from the original rodent data, also a similar value.

The major and insurmountable difficulty with all of these derivations is that all are based on application of TT to rodents and may not be appropriate for evaluating the potential toxicity of WT to humans.

\subsection{Weathering of toxaphene}

Toxaphene weathers in different ways in different environmental settings to produce different congener mixtures (Ruppe et al., 2003, 2004). In addition, different animals metabolize various toxaphene congeners to varying degrees (Angerhofer et al., 1999) and different species of animals end up with different toxaphene congener profiles comprising their respective body burdens. Both transformation of toxaphene mixtures by bacterial action in sediments or soils and metabolism in animals are considered forms of "weathering."

In animals, including human beings, differences in body burden are due to differences in the extent that individual congeners are metabolized and excreted. The major toxaphene congeners that persist in fish, marine mammals, human serum and human breast milk are p-26, p-40/41, p-44, p-50, and p-62. Barr et al. (2004) reported concentrations of toxaphene congeners from pooled human serum from three US cities. Only p-26 and p-50 were positively identified in the serum samples. There were indications that p-40/41, p-44, and p-62 were also present. Gill et al. (1996) presented methods for toxaphene congener analysis in serum and observed p-26, p-40/41, p-44, and p-50 in human serum extracts. Bjerregaard et al. (2001) measured toxaphene congeners in plasma of Inuit men and women in Greenland and found detectable levels of p-26, p-50, and p-62. Polder et al. (2003) measured p26 , p-50, and p-62 in human breast milk samples from Kargopol, Severodvinsk, Arkhangelsk, and Naryan-Mar, Russian towns all north of $60^{\circ}$ latitude. Skopp et al. (2002b) measured p-26, p-41, p-44, and p-50 in human breast milk obtained from mothers in the north Rhine area of Germany. Sandanger et al. (2003) measured organochlorines in the plasma of delivering mothers in northern Russia and found detectable concentrations of $\mathrm{p}-26$ and p-50; p-32, p-38, p-40, p-42, p-44, p-51, p-58, p-62, and p-69 were not detected. Walker et al. (2003) found detectable concentrations of $\mathrm{p}-26$ and $\mathrm{p}-50$ in maternal and umbilical cord blood plasma from mothers and newborns in northern Canada; p-32, p-62, and p-69 were analyzed but not detected. Average percentages of the congeners in the human body burden were calculated based on these five sources and are shown in Table 2 . These three congeners, $\mathrm{p}-26, \mathrm{p}-50$, and $\mathrm{p}-62$, comprise about $90 \%$ of the average human body burden.
Table 2

Toxaphene congeners and their average percentages in the human body burden from Gill et al. (1996), Polder et al. (2003), Skopp et al. (2002b), Sandanger et al. (2003), Walker et al. (2003)

\begin{tabular}{llllll}
\hline Congener & $\mathrm{p}-26$ & $\mathrm{p}-40 / 41$ & $\mathrm{p}-44$ & $\mathrm{p}-50$ & $\mathrm{p}-62$ \\
\hline Percent in human body burden & $32.8 \%$ & $2.7 \%$ & $3.5 \%$ & $54.7 \%$ & $6.3 \%$ \\
\hline
\end{tabular}

Metabolism and excretion of toxaphene occurs relatively rapidly in biological systems. These processes are also considered a form of "weathering." Oral administration of toxaphene to mammals and birds results in fecal passage of about $40 \%$ of the administered chemical and metabolism and urinary excretion of the remaining toxaphene on a time scale of weeks (Andrews et al., 1996; Biessman et al., 1983; Pollock and Hillstrand, 1982; Pollock and Kilgore, 1980; Mohammed et al., 1983). Only five or six persistent congeners remain in the tissues of mammals and birds. Because of this rapid "weathering," the exposure of higher animals to TT or WT is essentially equivalent to $\sum 3 \mathrm{PC}$ exposure, and any toxic effects are very likely due to $\sum 3 \mathrm{PC}$.

\subsection{Evaluation of risk of tumor promotion using a reference dose and threshold approach}

EPA recently released the cancer guidelines (USEPA, 2005). The greatest emphasis in these guidelines is placed on understanding the mode of action of potential carcinogens and taking the mode of action into account when developing a toxicity criterion. The guidelines include the possibility that nonlinear threshold models of cancer will be considered as the basis of regulatory toxicity criteria. Ideally, for threshold carcinogens, sufficient data above and below the dose threshold would exist to perform dose response modeling (USEPA, 2000); in cases where such modeling is not feasible, it is appropriate to use the reference dose approach for evaluation of cancer-associated chemical such as a tumor promoter that exhibits a dose threshold.

The reference dose (RfD) derived here is based on a noobserved-adverse-effect-level (NOAEL) from an in vivo study in rats administered WT via weekly subcutaneous injection (Besselink et al., 2000; MATT, 2000). WT was produced by "weathering" technical toxaphene for 2 months in farmed codfish. Cod liver extract (CLE) was then used as a source of WT. Concentrations of the three persistent congeners in CLE were available for all doses (Besselink et al., 2000; MATT, 2000). The critical effect was the occurrence of altered hepatic foci (AHF) expressing placental glutathione- $S$-transferase (GSTp-AHF). These foci are as an indication of tumor promotion (Ito et al., 1989; Krutovskikh et al., 1991). Additional mechanistic support for endpoint of tumor promotion is provided by an in vitro study of the disruption of gap junctional intercellular communication in the Hepa1c1c7 mouse liver cell line from exposure to WT (Besselink et al., 2000; MATT, 2000). 
Because the RfD derived here is based on the toxicity of the three persistent congeners, $\mathrm{p}-26, \mathrm{p}-50$, and $\mathrm{p}-62$, it is not directly comparable with other toxicity criteria for TT and WT. EPA's cancer slope factor for technical toxaphene has different units than the RfD. The tolerable daily intake (TDI) for WT derived in MATT (2000) is based on the entire WT mixture and the percentage of $\sum 3 \mathrm{PC}$ may be different in different WT mixtures.

\subsection{Applying the RfD to obtain a cleanup level}

If the percentage of $\sum 3 \mathrm{PC}$ in a WT mixture is known, then cleanup levels may be expressed either in terms of $\sum 3 \mathrm{PC}$ or in terms of WT by back calculation to the appropriate WT concentration based on the percentage of $\sum 3 \mathrm{PC}$ in the mixture. Cleanup levels based the RfD for $\sum 3 \mathrm{PC}$ may need to be expressed in terms of WT for comparison with cleanup levels based on other toxaphene toxicity criteria. A numerical comparison and sample calculations are provided in Section 4. In addition, the analytical methods used need to be considered; different methods give different analytical results (de Geus et al., 2000)

\section{Derivation of a reference dose for tumor promotion based on appearance of GSTp-AHF in rat liver}

The sole set of toxicity studies that used WT and measured $\sum 3 \mathrm{PC}$ in the WT mixture was conducted as part of the European effort, "Investigation into the Monitoring, Analysis, and Toxicity of Toxaphene." (MATT, 2000). These toxicity studies were also published separately (Besselink et al., 2000). Here, we use the results of these toxicity studies to derive an RfD for $\sum 3 \mathrm{PC}$.

The standard methods for developing reference doses have been published elsewhere and are well known (Barnes and Dourson, 1988). A three-step process for the derivation of an RfD was followed: (1) choice of a critical effect for $\sum 3 \mathrm{PC}$; (2) derivation of NOAELs for $\sum 3 \mathrm{PC}$ from the in vivo study in the MATT (2000); (3) choice and application of appropriate uncertainty factors.

\subsection{Critical effect of $\sum 3 P C$}

Based on the early rodent studies, the critical effect for TT was liver cancer (e.g., Goodman et al., 2000). Three possibilities for the critical effect of $\sum 3 \mathrm{PC}$ are considered: (1) $\sum 3 \mathrm{PC}$ acts as a genotoxic carcinogen; (2) $\sum 3 \mathrm{PC}$ acts as a developmental toxicant; (3) $\sum 3 \mathrm{PC}$ acts as a carcinogen via tumor promotion. If $\sum 3 \mathrm{PC}$ acts as a genotoxic carcinogen, then derivation of a cancer slope factor rather than a reference dose would be appropriate. If $\sum 3 \mathrm{PC}$ acts as either a developmental toxicant or a tumor promoter and if these effects have dose thresholds, then derivation of a reference dose is appropriate.

Recently, EPA has begun an effort to "harmonize" cancer and non-cancer risk assessment (USEPA, 1997b, 1998). The use of an $\mathrm{RfD}$ for tumor promotion is consistent with this "harmonization" effort. Colloquia held regarding the framework for human health risk assessment included harmonization of cancer and non-cancer endpoints. These colloquia stressed that understanding the mode of action of a particular effect was key in understanding toxicity and arriving at a meaningful regulatory toxicity criterion. The development of an RfD for the tumor promoting effect of the persistent congeners of toxaphene that comprise the human body burden is consistent with this effort to harmonize cancer and noncancer risk assessment, and, as already discussed, also consistent with EPA's cancer guidelines (USEPA, 2005).

It is appropriate to consider studies on the toxicity of TT when considering WT because the ultimate toxicants are the persistent congeners, present in both TT and WT. In fact, consideration of the toxicity of TT in a risk assessment for $\sum 3 \mathrm{PC}$ is similar to the practices in EPA's pesticide program. In that program, because many pesticides produce their effects through metabolites, the pesticides can be administered in animal studies to ascertain the toxic effect of the metabolites, so called "auto-testing."

What follows is a discussion of the likelihood and possible thresholds of these three possible effects of WT and the rationale for choosing tumor promotion as the critical effect.

\subsubsection{Genotoxicity of TT or WT}

In some studies with prokaryotic systems, TT has been shown to be mutagenic in the Ames test and others. Both TT and WT have been shown to be mutagenic in the Ames test (Young and Freeman, 2001, 2004), but the mutagenicity of WT appears less than that of TT (Steinberg et al., 1998). Bartos et al. (2005) showed both TT and WT to be genotoxic in some bacterial systems, but activation of TT by human microsomal preparations produced a negative result in the Ames test with salmonella TA 98 and TA 100, which contain the pKm101 plasmid. In other work, activation of TT by rat S9 liver fraction produced a positive Ames test in these strains (Hooper et al., 1979; Mortelsman et al., 1986).

In eukaryotic systems, the picture is even less clear. Mutagenicity of TT could not be shown in the mouse dominant lethal assay (NTP, 1979). In studies of sister chromatid exchange in Chinese hamster lung cells and human lymphocyte cultures, TT produced a weak response that was reduced by metabolic activation (Sobti et al., 1983; Steinel et al., 1990). Toxaphene was clearly not a mutagen in the mouse dominant lethal assay (Epstein et al., 1972). Boon et al. (1998) observed genotoxicity for TT as well as four toxaphene congeners ( $\mathrm{p}-26, \mathrm{p}-32, \mathrm{p}-50$, and $\mathrm{p}-62)$ in the Mutatox assay. Addition of rat S9 fraction or microsomes of harbour seal or albatross decreased the genotoxic potential of single congeners and TT. This indicates that organisms with a lower capacity to metabolize toxaphene might be more susceptible to the mutagenic effects of TT than organisms with a greater metabolic capacity.

In humans, EPA did not observe leukocyte chromosomal aberrations in agricultural workers using toxaphene 
(USEPA, 1978). However, an accidental exposure of eight women to airborne toxaphene resulted in an increase in chromosomal aberrations (Samosh, 1974).

There is certainly no clear and convincing evidence that TT or WT are genotoxic in humans and the critical effect of cancer via a genotoxic mechanism was not considered further.

\subsubsection{Developmental effects of toxaphene}

Calciu et al. (1997) investigated the effects of TT, p-26, p-50 and an equimolar mixture of p-26/p-50 on the development of cultured rat embryos. The concentrations used were 100,1000 and $5000 \mathrm{ng} / \mathrm{ml}$. All treatments caused growth retardation of the embryos at all doses. These authors suggest that levels of toxaphene in umbilical cord blood estimated from measured levels in breast milk of Inuit women are 1/1000 of the lowest concentrations used in the experiment.

Calciu et al. (2002) discovered an interaction between TT, p-26, and p-50, on one hand, and hyperglycemia, on the other hand, that affected the development of cultured rat embryos. The dose range was 100, 1000, and $5000 \mathrm{ng} /$ $\mathrm{ml}$. Again, the levels of toxaphene or individual congeners used appear to be at least 1000 times greater than the levels of toxaphene predicted in cord blood based on plasma levels in Inuit women (Bjerregaard et al., 2001) and Calciu et al. (2002) concluded that observing effects in humans would be unlikely. Thus, while both TT and WT may produce developmental toxicity, it appears that the concentrations required to do so are much higher than body burden concentrations in a highly exposed human population.

Because TT and the two congeners were added directly to the culture medium containing the rat embryos, it is impossible from this in vitro experiment to determine an estimate of the dose that would be associated with human developmental effects. Nonetheless, a LOEC (Lowest Observed Effective Concentration) of $100 \mathrm{ng} / \mathrm{ml}$ or $100 \mu \mathrm{g} / \mathrm{L}$ can be established for TT, p-26, and p-50 from this study.

\subsubsection{Toxaphene as a tumor promoter}

Inhibition of gap junctional intercellular communication (GJIC) has been postulated to release initiated cells from suppressing effects of signals passing from surrounding cells (Kao et al., 1995; Yamasaki, 1990). Disruption of gap junctional communication can be measured by intercellular transfer of the dye Lucifer yellow following application of the tumor promoter 12-O-tetradecanoylphorbol-13-acetate (TPA) (McKarns and Doolittle, 1982). A study by Kang et al. (1996) showed that noncytotoxic concentrations of TT inhibited GJIC in normal human breast epithelial cells in a dose-dependent way after 90 min of exposure.

The appearance of GSTp-AHF is associated with a decrease in GJIC with surrounding cells and eventual progress to cancer (Ito et al., 1989; Krutovskikh et al., 1991). This effect appears to be due to reduced expression of con- nexins, the gap junction forming protein (Fitzgerald et al., 1989). However, the association is not complete and disruption of gap junctions and down-regulation of connexins, on one hand, and the expression of GSTp, on the other hand, may represent two distinct pathways to tumor formation (Bager et al., 1997). Toxaphene and other nongenotoxic carcinogens have been shown to disrupt GJIC (Kang et al., 1996; Kolaja et al., 2000).

Based on these earlier studies, Besselink et al. (2000) investigated the tumor promoting effects of WT using both in vivo and in vitro assays. The cod liver extract used in the MATT study clearly disrupted gap junctions in mouse Hepalc1c7 cells at all concentrations tested (Besselink et al., 2000) and tumor promotion is considered the most likely endpoint for WT.

\subsection{Description of the study providing the critical effect}

\subsubsection{Preparation of weathered toxaphene mixture}

Weathered toxaphene was prepared by dosing codfish with $30 \mathrm{ppm}$ TT via feed pellets for two months. Cod liver extracts (CLE) were used as the source of weathered toxaphene. At the conclusion of the feeding period, a total of $1880 \mathrm{mg}$ of toxaphene residue was obtained from the pooled cod livers (MATT, 2000). Analysis of the CLE revealed a mixture of many toxaphene congeners, including p-26, p-50, and p-62. As indicated, because of rapid metabolism and excretion of the non-persistent congeners, exposure of mammals to technical toxaphene or WT mixtures is essentially equivalent to exposure to $\sum 3 \mathrm{PC}$, and any toxic effects are likely due to $\sum 3 \mathrm{PC}$.

A chromatogram provided in the MATT report shows that the CLE was considerably enriched in p-26, p-32, p50 , and p-62. However, the mixture of toxaphene residues in CLE was complex and contained more individual congeners than weathered toxaphene obtained from other biotic sources (Chan et al., 1998; Chan and Yeboah, 2000; Skopp et al., 2002a; Maruya, 2000). Technical toxaphene was weathered in cod for two months only to produce CLE. The percentage of $\sum 3 \mathrm{PC}$ in CLE was between 0.2 and $0.3 \%$, which was much lower than the percentage observed in WT from environmental sources (e.g., Tables 6 and 7) The low percentage of $\sum 3 \mathrm{PC}$ in CLE may be related to the short period of weathering.

\subsubsection{In vivo study of tumor promotion}

Female Sprague-Dawley rats in groups of three or four animals were given partial hepatectomies at the age of 6 weeks. Diethylnitrosamine $(30 \mathrm{mg} / \mathrm{kg})$ was given by intraperitoneal injection $24 \mathrm{~h}$ after hepatectomy. Beginning 5 weeks later and lasting for 20 weeks, the rats were then dosed weekly via subcutaneous injection with either technical toxaphene (TT), UV-treated toxaphene (UVT), cod liver extract (CLE) or dioxin (2,3.7.8-TCDD) in a corn oil vehicle. The lowest concentration of CLE in the in vivo study was $0.46 \mathrm{mg} / \mathrm{ml}$ corn oil and the highest concentration was $12.5 \mathrm{mg} / \mathrm{ml}$ corn oil. $1 \mathrm{ml}$ of corn oil 
was administered subcutaneously per week. MATT (2000) indicates these dosing concentrations are expressed as UVT-equivalents whereas Besselink et al. (2000) report these numeric values only.

Presumably, because UV treatment is another means of weathering toxaphene, the doses in CLE were expressed as UVT equivalents, although both MATT (2000) and Besselink et al. (2000) failed to provide the details of this equivalence or the rationale for the UV treatment. Here, the concentrations of $\sum 3 \mathrm{PC}$ were used as the basis of the RfD dose because these are the predominant congeners in the human body burden. Concentrations of p-26, p-50, and p-62 in CLE were provided in MATT (2000) and the details of the UVT equivalence are not necessary.

A range of doses of TT, UVT, and CLE were given to the rats. A single dose of dioxin was given as a positive control. One week after the last dose, the rats were sacrificed and their livers obtained (Besselink et al., 2000; MATT, 2000).

The endpoint of the in vivo assay was the production of GSTp-AHF. Only TCDD produced positive foci. The lower three doses of CLE were not significantly different from the corn oil control in terms of the number of GSTp-AHF. The highest dose showed a decrease in GSTp-AHF, indicating some possible cytotoxic effect that may not be related to tumor promotion.

The ratios of the three persistent congeners in the doses used in the in vivo assay approximate those observed in biotic samples (Table 5). Hence, $\sum 3 \mathrm{PC}$ is approximately proportional to the dose of WT. The concentrations of the three persistent congeners in the rats' livers were mea- sured at the end of the experiment. Only the highest dose $(12.5 \mathrm{mg} / \mathrm{kg}$-week) resulted in detectable liver concentrations with detections of 2 and $3 \mu \mathrm{g} / \mathrm{kg}$ wet weight for p-50 and p-62, respectively, and a nondetect analytical result for p-26 (Table 3).

Because of the difficulty of interpreting the in vivo results observed at the highest dose of CLE $(12.5 \mathrm{mg} / \mathrm{kg}$ week), the next highest dose was considered a NOAEL. At this next highest dose of $4.17 \mathrm{mg} / \mathrm{kg}$-week as UVT equivalents, the number of GSTp-AHF was not significantly different from the number of GSTp-AHF in corn oil controls. This dose is equivalent to $0.0021 \mathrm{mg} / \mathrm{kg}$-day of $\sum 3 \mathrm{PC}$ (Table 2). However, with this dose of $4.17 \mathrm{mg} / \mathrm{kg}$ week CLE as UVT equivalents, concentrations of $\mathrm{p}-26$, p-50, and p-62 in the rats' livers were below analytical detection limits (Table 3).

\subsubsection{In vitro study of gap junctional intercellular communication}

The in vitro study measured intracellular communication between mouse Hep1c1c7 cells in culture by observing the spread of Lucifer Yellow dye between adjacent cells. This dye has been used for a number of years to observe disruption of gap junctional communication and electrical junctions between nerve cells. (e.g., McKarns and Doolittle, 1982; Spencer and Satterlie, 1980). 2,3,7,8-TCDD was used as a positive control. A dose-dependent response was observed for CLE in this assay. The lowest concentration for CLE extract in the in vitro study was $1 \mathrm{mg} / \mathrm{ml}$ (Besselink et al., 2000). In the in vitro study, an effect was observed at $1 \mathrm{mg} / \mathrm{ml}$ - hence, this concentration represents

Table 3

Percentage of p-26, p-50, and p-62 in the MATT dosing vehicle and calculated doses of $\sum 3$ PC in the in vivo study

\begin{tabular}{|c|c|c|c|c|}
\hline Concentration UV-T equivalents ( $\mathrm{mg} / \mathrm{ml}$ oil) & 0.46 & 1.39 & 4.17 & 12.5 \\
\hline \multicolumn{5}{|l|}{ Concentration ( $\mu \mathrm{g} / \mathrm{ml}$ oil) } \\
\hline p-26 & 0.3 & 1.2 & 3.4 & 9.9 \\
\hline $\mathrm{p}-50$ & 0.4 & 2 & 5.5 & 16.8 \\
\hline $\mathrm{p}-62$ & 0.4 & 2.1 & 6 & 17.5 \\
\hline$\sum 3 \mathrm{PC}$ & 1.1 & 5.3 & 14.9 & 44.1 \\
\hline \multicolumn{5}{|l|}{ Percentages of three congeners in CLE } \\
\hline$\% \mathrm{p}-26$ & 0.065 & 0.086 & 0.082 & 0.079 \\
\hline$\% \mathrm{p}-50$ & 0.087 & 0.144 & 0.132 & 0.134 \\
\hline$\% \mathrm{p}-62$ & 0.087 & 0.151 & 0.144 & 0.140 \\
\hline$\sum 3 \mathrm{PC}$ & 0.239 & 0.381 & 0.357 & 0.354 \\
\hline \multicolumn{5}{|l|}{ Doses (mg/kg-day) used in the in vivo study } \\
\hline CLE as UVT & 0.066 & 0.198 & 0.60 & 1.79 \\
\hline $\mathrm{p}-26$ & $4.28 \mathrm{E}-05$ & 0.00017 & 0.00049 & 0.0014 \\
\hline $\mathrm{p}-50$ & $5.71 \mathrm{E}-05$ & 0.00029 & 0.00079 & 0.0024 \\
\hline p-62 & $5.71 \mathrm{E}-05$ & 0.00030 & 0.00086 & 0.0025 \\
\hline$\sum 3 \mathrm{PC}$ & $1.57 \mathrm{E}-04$ & 0.00076 & 0.0021 & 0.0063 \\
\hline \multicolumn{5}{|l|}{ Liver concentrations in the in vivo study $(\mu \mathrm{g} / \mathrm{kg})$} \\
\hline $\mathrm{p}-26$ & $<0.4$ & $<0.4$ & $<0.5$ & $<1.0$ \\
\hline $\mathrm{p}-50$ & $<0.5$ & $<0.4$ & $<0.5$ & 2 \\
\hline p-62 & $<0.5$ & $<0.5$ & $<0.5$ & 3 \\
\hline$\sum 3 \mathrm{PC}$ & $<1.4$ & $<1.3$ & $<1.5$ & $5-6$ \\
\hline
\end{tabular}

The chosen NOAEL is in boldface and highlighted. 
a LOEC for CLE. The corresponding LOEC for $\sum 3 \mathrm{PC}$ based on a concentration of CLE of $1 \mathrm{mg} / \mathrm{ml}$ would be $2.4 \mu \mathrm{g} / \mathrm{ml}$ because the percentage of $\sum 3 P C$ in CLE at the lowest dosing concentration is $0.24 \%$ (Table 3 ).

Kang et al. (1996) used technical toxaphene in an in vitro assay of GJIC in normal human breast epithelial cells and observed a LOEC of $1.25 \mathrm{mg} / \mathrm{ml}$. This result is not directly comparable to those from MATT (2000) because of three factors: (1) the differences between WT and TT; (2) the fact that the percentage of $\sum 3 \mathrm{PC}$ in TT used by Kang et al. (1996) is not known; and (3) an internal discrepancy in Kang et al. (1996) whether toxaphene concentrations were expressed in $\mathrm{mg} / \mathrm{ml}$ or $\mu \mathrm{g} / \mathrm{ml}$.

\subsection{Determination of a NOAEL for tumor promotion from the MATT study}

Generally, it is preferable to develop a point of departure for an adverse effect using benchmark dose modeling (USEPA, 2000). These models use all the data from dose response studies instead of a NOAEL or LOAEL. However, in the in vivo study (Besselink et al., 2000; MATT, 2000), the doses were not high enough to observe a doseresponse curve or even a LOAEL.

The doses of $\sum 3 \mathrm{PC}$ were recalculated based on the rats' initial average body weights and average weight gains given in Table 4 of chapter 5 of the MATT report. These doses are also shown in Table 3 of this paper.

As indicated, at the highest in vivo dose of $12.5 \mathrm{mg} / \mathrm{kg}$ week CLE, there was a reduction in the number of GSTpAHF in the rats' livers compared with the number in controls and the highest dose group result was not considered usable. No differences were observed in the number or size of GSTp-AHF foci at the three lower doses. The highest dose of these three $(4.17 \mathrm{mg} / \mathrm{kg}$-week CLE as UVT equivalents) was below the dose threshold for observing the critical effect. Hence, this dose of $4.17 \mathrm{mg} / \mathrm{kg}$-week CLE or
$0.002 \mathrm{mg} / \mathrm{kg}$-day of $\sum 3 \mathrm{PC}$ can be considered a NOAEL (Table 3).

The rats' liver concentrations of $\mathrm{p}-26, \mathrm{p}-50$, and $\mathrm{p}-62$ were measured at the conclusion of the study. This information was presented in MATT (2000) but not in Besselink et al. (2000). At the highest dose of $12.5 \mathrm{mg} / \mathrm{kg}$-week of CLE, the concentration in the rats' livers of $\sum 3 \mathrm{PC}$ was less than $6 \mu \mathrm{g} / \mathrm{kg}$ wet weight (Table 3 in chapter 5 of MATT (2000) and Table 3 here). At lower doses, the concentrations of the three persistent congeners were below analytical detection limits.

To compare the internal liver concentration of $\sum 3 \mathrm{PC}$ in the in vivo study with the LOEC from the in vitro study, one can multiply the percentage of $\sum 3 \mathrm{PC}$ and the CLE concentration. The in vitro LOEC for CLE was $1 \mathrm{mg} / \mathrm{ml}$ (Besselink et al., 2000). The percentage of $\sum 3$ PC in CLE at this lowest dose level was $0.24 \%$. Hence, assuming the intact rat liver cells are similarly susceptible to interruption of GJIC as the Hep1c1c7 cells, the potentially effective concentration of $\sum 3 \mathrm{PC}$ in the rats' livers would be $0.24 \%$ of the in vitro LOEC of $1 \mathrm{mg} / \mathrm{ml}$ or $2.4 \mu \mathrm{g} / \mathrm{ml}$ of $\sum 3 P C$. Expressing this value in the same units as $\sum 3 \mathrm{PC}$ in the rats' livers (Table 2), it becomes $2400 \mu \mathrm{g} / \mathrm{L}$ (assuming $1 \mathrm{~kg}$ of tissue occupies $1000 \mathrm{ml}$ ). Hence, this LOEC is 400 times larger than the largest liver concentration observed, approximately $6 \mu \mathrm{g} / \mathrm{kg}$ of $\sum 3 \mathrm{PC}$.

The NOAEL for $\sum 3 \mathrm{PC}$ based on the dose given the rats in the in vivo study and the percentage in the CLE mixture is $0.002 \mathrm{mg} / \mathrm{kg}$-day and corresponds to $4.17 \mathrm{mg}$ CLE per $\mathrm{ml}$ of corn oil (Table 3).

\subsection{Application of uncertainty factors applied to obtain an RfD for tumor promotion}

The usual uncertainty factors of 10 for animal-to-human extrapolation and 10 for human variability result in a combined UF of 100 . To support this value, it is

Table 4

Margin of exposure for developmental effects among the Inuit based on developmental effects in cultured rat embryos

\begin{tabular}{|c|c|c|c|c|c|c|}
\hline \multirow[t]{2}{*}{ Chemical } & \multirow[t]{2}{*}{$\begin{array}{l}\text { Daily intake } \\
(\mu \mathrm{g} / \mathrm{kg} \text {-day) }\end{array}$} & \multicolumn{2}{|c|}{$\begin{array}{l}\text { Median maternal plasma or cord } \\
\text { blood conc. }(\mu \mathrm{g} / \mathrm{L})\end{array}$} & \multirow[t]{2}{*}{$\begin{array}{l}\text { Effect level (Calciu et al., 1997, 2002) } \\
(\mu \mathrm{g} / \mathrm{L})\end{array}$} & \multicolumn{2}{|c|}{ Margin of exposure } \\
\hline & & $\begin{array}{l}\text { Walker et al. } \\
(2003)\end{array}$ & $\begin{array}{l}\text { Sandanger et al. } \\
(2003)\end{array}$ & & $\begin{array}{l}\text { Walker et al. } \\
(2003)\end{array}$ & $\begin{array}{l}\text { Sandanger et al. } \\
(2003)\end{array}$ \\
\hline $\mathrm{p}-26$ & $0.010^{\mathrm{a}}$ & 0.02 & 0.05 & $100^{\mathrm{b}}$ & 5000 & 2000 \\
\hline$p-50$ & $0.016^{\mathrm{a}}$ & 0.03 & 0.09 & 100 & 2000 & 1111 \\
\hline
\end{tabular}

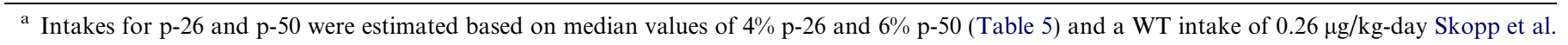
(2002b), Chan and Yeboah (2000), Chan et al. (1997).

b Effect level concentration for TT, p-26 or p-50.

Table 5

Preliminary remediation goals (PRGs) USEPA (2004b) for weathered toxaphene

\begin{tabular}{|c|c|c|c|c|}
\hline Medium & Residential soil (mg/kg) & Industrial soil (mg/kg) & Air $(\mu \mathrm{g} / \mathrm{m} 3)$ & Water $(\mu \mathrm{g} / \mathrm{L})$ \\
\hline Percentage of $\sum 3 \mathrm{PC}$ in WT & 10 & 10 & 8.8 & 5 \\
\hline$\sum 3 \mathrm{PC}$ PRG & 1.2 & 12 & 0.07 & 0.03 \\
\hline Corresponding WT PRG & 12 & 120 & 0.8 & 0.6 \\
\hline
\end{tabular}


necessary to consider possible developmental effects and database insufficiencies, which might add additional uncertainty factors.

\subsubsection{Margin of exposure for developmental effects of toxaphene}

The rat embryo studies of Calciu et al. $(1997,2002)$ provide a LOEC value of $100 \mu \mathrm{g} / \mathrm{L}$. One can compare this value with plasma concentrations in highly exposed humans. Generally, extrapolation from in vitro effects to potential in vivo effects is not typically performed. Nonetheless, a margin-of-exposure (MOE) can be calculated as the ratio between this LOEC and actual plasma levels in these highly exposed humans as an estimate of the likelihood of developmental effects in humans. The larger the value of this MOE, then the less the need for an additional uncertainty factor for possible developmental effects.

Both the Inuit, a circumpolar aboriginal population in Canada and Greenland, and people living in northern Russia, have high intakes of WT because of their dependence on fish and marine mammals as a food source (Arbour et al., 2004; Bjerregaard et al., 2001; Receveur et al., 1998; Sandanger et al., 2003; Van Oostdam et al., 2005; Walker et al., 2003). Mean plasma levels in delivering mothers (Sandanger et al., 2003) and mean umbilical cord blood levels (Walker et al., 2003) of toxaphene congeners can be compared to the LOEC for developmental effects in rat embryos (Calciu et al., 1997, 2002).

Table 4 shows these values and provides a calculation of the margin of exposure for frank effects based on the rat embryo data with p-26 and p-50 as the toxicants (Calciu et al., 1997). The MOEs for both p-26 and p-50 are for both human studies greater than 1000. It is also noteworthy that the rats administered the NOAEL value of CLE failed to accumulate any measurable amount of any toxaphene congeners in their livers (Besselink et al., 2000; MATT, 2000). hence, a much higher external dose than the NOAEL would be needed to produce an internal concentration similar to that of $100 \mu \mathrm{g} / \mathrm{L}$ used by Calciu et al. (1997).

There is no evidence that the Inuit experience greater developmental health effects due to toxaphene exposure than do developed societies (Faustman et al., 2000; Landrigan et al., 2002). Birth defects among the Inuit have been attributed to other causes such as nutrition and alcoholism and increasing "Westernization" of their culture (Arbour et al., 2004; Macaulay et al., 2004). Hence, it is likely that the level of human intake that results in the measured plasma and cord blood levels shown in Table 4 is well below the threshold for developmental effects.

\subsubsection{Estimate of a NOAEL based on human intakes of toxaphene congeners}

Estimates of daily WT intakes from fish and biota among the Inuit (Chan et al., 1997) can be used to estimate daily intake and compare this to the NOAEL in rats based on GSTp-AHF. The 95th percentile estimated intake for
Inuit females is $2.6 \mu \mathrm{g} / \mathrm{kg}$-day. Using the average percentage value of $\sum 3 \mathrm{PC}$ in fish of $22.5 \%$ (Table 6 ), the 95th percentile $\sum 3 \mathrm{PC}$ intake would be $0.0006 \mathrm{mg} / \mathrm{kg}$-day, about one-third of the NOAEL value of $0.002 \mathrm{mg} / \mathrm{kg}$-day. Hence, it is very likely that an RfD derived from the rat NOAEL will be protective of developmental effects in humans.

\subsubsection{Other potential toxic effects of toxaphene}

Other endpoints were considered, although in less detail than those discussed above. These other endpoints were studied using TT, (Andrews et al., 1996; Biessman et al., 1983; Pollock and Hillstrand, 1982; Pollock and Kilgore, 1980; Mohammed et al., 1983). Because of the rapid metabolism and excretion of TT in higher animals and the concept of "auto-testing" as previously discussed, TT studies are appropriate for contributing to the breadth of endpoints considered for $\sum 3 \mathrm{PC}$ and contribute to the strength of the database regarding potential effects of $\sum 3 \mathrm{PC}$. However, these other studies are not directly comparable to the NOAEL for $\sum 3 \mathrm{PC}$ because the concentration of $\sum 3 \mathrm{PC}$ in these studies was not known. However, these studies can be compared to the NOAEL expressed as the dose of CLE, which is $0.6 \mathrm{mg} / \mathrm{kg}$-day (Table 3 ).

Both Arnold et al. (2001) and Bryce et al. (2001) observed a decrease in serum cholesterol in Cynomolgus monkeys in monkeys given doses of $0.8 \mathrm{mg} / \mathrm{kg}$-day and $1 \mathrm{mg} / \mathrm{kg}$-day respectively. Tryphonas et al. $(2000,2001)$ observed immunologic effects in Cynomologous monkeys dosed with TT. The NOAEL for these effects is $0.1 \mathrm{mg} /$ kg-day. Olson et al. (1980) observed neurodevelopmental effects in rats for TT with a LOAEL of $0.5 \mathrm{mg} / \mathrm{kg}$-day. $\mathrm{Chu}$ et al. (1988) observed liver effects in rats with a NOAEL of $0.35 \mathrm{mg} / \mathrm{kg}$-day and thyroid effects with a NOAEL of $0.18 \mathrm{mg} / \mathrm{kg}$-day. All of these point-of-departure values are similar to the NOAEL of $0.6 \mathrm{mg} / \mathrm{kg}$-day for the CLE mixture and an uncertainty factor for database insufficiency is not necessary.

\subsubsection{Toxaphene congeners and human cancer}

With regard to breast cancer specifically, TT, p-26, and p-50 all enhance proliferation of MCF7-E3 human breast cancer estrogen-sensitive cells in vitro (Stelzer and Chan, 1999). In this same cell line, TT, p-26, and p-60 have weak anti-estrogenic properties and can potentially disturb the intracellular signaling mediated by the estrogen receptor (Arcaro et al., 2000; Bonefield et al., 1997) and a link has been suggested between toxaphene and breast cancer. In addition, toxaphene disrupts GJIC and expression of gap junction proteins in normal human breast epithelial cells (Kang et al., 1996). However, the highly expose Inuit have been shown to have very low breast cancer rates, about 1 / 10 of the average rate in Canada (Gaudette et al., 1996; Miller and Gaudette, 1996).

With regard to cancer, there is also currently no definitive evidence that the circumpolar Inuit experience greater cancer risk due to toxaphene exposure than developed societies. The Inuit present a dissimilar picture when one 
Table 6

Percentages of three congeners in total toxaphene concentrations in various biotic samples (based on ng/g wet weight)

\begin{tabular}{|c|c|c|c|c|c|}
\hline Source & $\% \mathrm{p}-26$ & $\% \mathrm{p}-50$ & $\% \mathrm{p}-62$ & $\% \sum 3 \mathrm{PC}$ & Reference \\
\hline King Salmon & 4.12 & 5.76 & 9.41 & 19.29 & Chan and Yeboah (2000) \\
\hline Dogfish & 4.09 & 5.16 & 9.14 & 18.39 & Chan and Yeboah (2000) \\
\hline King Salmon & 4.11 & 6.56 & 7.67 & 18.33 & Chan and Yeboah (2000) \\
\hline King Salmon & 3.70 & 6.30 & 7.26 & 17.26 & Chan and Yeboah (2000) \\
\hline King Salmon & 4.59 & 6.89 & 10.00 & 21.49 & Chan and Yeboah (2000) \\
\hline Whitefish & 3.50 & 6.50 & 9.75 & 19.75 & Chan and Yeboah (2000) \\
\hline King Salmon & 4.00 & 5.00 & 7.67 & 16.67 & Chan and Yeboah (2000) \\
\hline King Salmon & 3.66 & 5.00 & 7.93 & 16.59 & Chan and Yeboah (2000) \\
\hline Trout & 3.96 & 3.96 & 6.04 & 13.96 & Chan and Yeboah (2000) \\
\hline King Salmon & 3.08 & 5.94 & 6.78 & 15.80 & Chan and Yeboah (2000) \\
\hline King Salmon & 5.00 & 7.42 & 7.26 & 19.68 & Chan and Yeboah (2000) \\
\hline Halibut & 7.86 & 9.29 & 6.19 & 23.33 & Chan and Yeboah (2000) \\
\hline Ooligan & 2.26 & 2.71 & 4.71 & 9.68 & Chan and Yeboah (2000) \\
\hline Chum Salmon & 2.84 & 4.33 & 6.72 & 13.88 & Chan and Yeboah (2000) \\
\hline Trout & 5.02 & 6.39 & 13.24 & 24.66 & Chan and Yeboah (2000) \\
\hline Trout & 4.12 & 7.41 & 10.70 & 22.22 & Chan and Yeboah (2000) \\
\hline Trout & 4.42 & 7.28 & 13.11 & 24.81 & Chan and Yeboah (2000) \\
\hline Sockeye & 2.29 & 1.98 & 3.75 & 8.02 & Chan and Yeboah (2000) \\
\hline Lake Trout & 6.36 & 5.45 & 11.82 & 23.64 & Chan and Yeboah (2000) \\
\hline SRM 1588 cod liver oil & 6.38 & 9.83 & 4.84 & 21.06 & Chan and Yeboah (2000) \\
\hline Burbot & 2.79 & 4.12 & 1.76 & 8.68 & Skopp et al. $(2002 a, b)$ \\
\hline Burbot & 6.88 & 5.74 & 2.10 & 14.72 & Skopp et al. (2002a,b) \\
\hline Muskox & 0.33 & 0.45 & & & Skopp et al. $(2002 a, b)$ \\
\hline Beluga & 14.01 & 25.07 & 0.80 & 39.88 & Skopp et al. $(2002 a, b)$ \\
\hline Narwhal & 16.41 & 20.00 & 2.24 & 38.65 & Skopp et al. (2002a,b) \\
\hline Walrus & 12.03 & 6.86 & 0.33 & 19.22 & Skopp et al. $(2002 a, b)$ \\
\hline Whitefish & 13.48 & 23.60 & & 40.45 & Chan et al. (1998) \\
\hline Lake Trout & 10.37 & 23.70 & & 40.37 & Chan et al. (1998) \\
\hline Narwhal & 29.99 & 25.40 & & 58.05 & Chan et al. (1998) \\
\hline Minimum & 0.33 & 0.45 & 0.33 & 8.02 & \\
\hline Maximum & 29.99 & 25.40 & 13.24 & 58.05 & \\
\hline Median & 4.12 & 6.39 & 7.26 & 19.49 & \\
\hline Average & 6.61 & 8.76 & 6.85 & 22.45 & \\
\hline
\end{tabular}

considers the relative frequencies of various types of cancers within the population; however, the etiology remains unclear (Gaudette et al., 1993; Nielsen et al., 1996).

For the reasons of the high MOE for developmental effects, the NOAEL based on human intake estimates, the plethora of TT studies on a variety of endpoints and the lack of concordance of laboratory and human population effects of toxaphene regarding cancer, an additional UF for developmental effects or database insufficiency will not be included and the combined UF is 100 .

Hence, the RfD for $\sum 3 \mathrm{PC}$ is $2 \mathrm{E}-05 \mathrm{mg} / \mathrm{kg}$-day.

\section{Estimating the risk consuming fish containing weathered toxaphene}

From the MATT (2000), the percentages of the three persistent congeners in the corn oil used as a dosing vehicle in the in vitro or in vivo studies (Table 2) are compared with the median values from the fish and shellfish concentrations obtained from sources at northern latitudes (Table 6) or from a Superfund site (Table 7). Note that the percentages of the three congeners are lower in the MATT dosing vehicle than in fish or biota from the environment. The reason for the lower percentage of $\sum 3 \mathrm{PC}$ in CLE may be that TT was weathered in codfish for only two months; over time, toxaphene residues in biota will become enriched in the persistent congeners and the fish and biota data in Tables 6 and 7 were obtained from tissue in which TT had been weathered for years.

As an example of a risk calculation with the $\sum 3 \mathrm{PC} \mathrm{RfD}$ derived here, data from fish and shellfish obtained from a Superfund site in the southeastern US were obtained from Maruya (2000). Ninety-five percent upper confidence limits on the arithmetic mean concentrations of WT and $\sum 3 \mathrm{PC}$ concentrations in the fish were calculated with PROUCL software (USEPA, 2004a). Finfish and shellfish concentrations in $\mathrm{ng} / \mathrm{g}$ wet weight were both included in the calculation. No weighting was used for angler preference of the two types of fish. WT concentrations were generally consistent with a lognormal distribution. Because several nondetect analytical results were present, the bootstrap- $t$ method was used for the UCL. The UCL value for WT was $5348 \mu \mathrm{g} /$ kg. $\sum 3 \mathrm{PC}$ concentrations were consistent with a gamma distribution and the adjusted gamma method was used for the UCL. The UCL value for $\sum 3 P C$ was $228 \mu \mathrm{g} / \mathrm{kg}$.

Fish ingestion rates for both children and adults were obtained from Tables 10-61 of the Exposure Factors Handbook (USEPA, 1997a). The highest value of 
Table 7

Percentages of the three congeners in total toxaphene concentrations in fish samples from a Superfund site

\begin{tabular}{|c|c|c|c|c|}
\hline Source & $\% \mathrm{p}-26$ & $\% \mathrm{p}-50$ & $\% \mathrm{p}-62$ & $\% \sum 3 \mathrm{PC}$ \\
\hline Black Drum & 2.71 & & & 2.71 \\
\hline Blue Crab & 6.09 & 1.50 & 0.33 & 7.92 \\
\hline Blue Crab & 4.72 & 2.37 & 1.09 & 8.19 \\
\hline Blue Crab & 5.39 & 2.86 & & 8.24 \\
\hline Blue Crab & 4.39 & & & 4.39 \\
\hline Blue Crab & 0.89 & 0.66 & & 1.56 \\
\hline Blue Crab & 2.10 & 2.15 & & 4.25 \\
\hline Blue Crab & 4.45 & 2.29 & 0.65 & 7.39 \\
\hline Blue Crab & 4.52 & 1.20 & & 5.72 \\
\hline Croaker & 2.39 & 0.59 & & 2.98 \\
\hline Croaker & 2.32 & 0.63 & & 2.95 \\
\hline Croaker & 2.24 & 0.41 & & 2.64 \\
\hline Croaker & 2.47 & 0.62 & & 3.10 \\
\hline Mullet & 4.19 & 1.37 & 0.73 & 6.29 \\
\hline Mullet & 1.94 & 1.91 & 0.74 & 4.59 \\
\hline Mullet & 3.62 & 1.47 & 0.47 & 5.55 \\
\hline Mullet & 2.59 & 0.92 & & 3.51 \\
\hline Mullet & 3.92 & 1.23 & 0.67 & 5.82 \\
\hline Mullet & 0.28 & 1.43 & 0.49 & 2.21 \\
\hline Mullet & 3.13 & 1.50 & 0.61 & 5.24 \\
\hline Mullet & 4.42 & 0.69 & & 5.11 \\
\hline Mullet & 4.03 & 1.57 & & 5.60 \\
\hline Red Drum & 3.37 & 1.29 & 0.64 & 5.29 \\
\hline Red Drum & 2.78 & 0.88 & 0.46 & 4.12 \\
\hline Red Drum & 2.85 & & & 2.85 \\
\hline Sea Trout & 3.92 & 1.40 & 0.54 & 5.86 \\
\hline Sea Trout & 0.92 & 1.05 & 0.70 & 2.67 \\
\hline Sea Trout & 3.19 & 0.92 & 0.53 & 4.63 \\
\hline Sea Trout & 2.54 & 0.50 & 0.24 & 3.28 \\
\hline Sea Trout & 2.09 & 0.57 & 0.25 & 2.91 \\
\hline Sea Trout & 3.19 & 0.70 & 0.42 & 4.31 \\
\hline Sea Trout & 3.65 & 1.04 & & 4.68 \\
\hline Shrimp & 4.61 & 2.84 & 0.66 & 8.11 \\
\hline Shrimp & 4.42 & 2.70 & 0.67 & 7.79 \\
\hline Shrimp & 2.73 & 1.57 & 0.55 & 4.85 \\
\hline Shrimp & 4.73 & 2.74 & 0.51 & 7.98 \\
\hline Shrimp & 4.06 & 3.43 & 1.21 & 8.69 \\
\hline Shrimp & 5.82 & 1.82 & & 7.63 \\
\hline Spot & 3.63 & 1.24 & 0.39 & 5.26 \\
\hline Spot & 4.08 & 1.39 & 0.29 & 5.76 \\
\hline Spot & 3.72 & 1.15 & 0.35 & 5.22 \\
\hline Spot & 3.23 & 1.02 & & 4.25 \\
\hline Spot & 3.51 & 0.76 & 0.36 & 4.63 \\
\hline Spot & 2.64 & 0.52 & & 3.15 \\
\hline Spot & 2.79 & 0.45 & 0.21 & 3.46 \\
\hline Spot & 3.20 & 0.65 & & 3.85 \\
\hline Spot & 2.05 & & & 2.05 \\
\hline Yellowtail & 3.20 & 1.01 & & 4.21 \\
\hline Yellowtail & 3.12 & 0.91 & 0.35 & 4.38 \\
\hline Yellowtail & 2.98 & 1.12 & 0.44 & 4.53 \\
\hline Flounder & 3.54 & & 0.71 & 4.26 \\
\hline Whiting & 3.45 & & & 3.45 \\
\hline Minimum & 6.09 & 3.43 & 1.21 & 8.69 \\
\hline Maximum & 0.28 & 0.41 & 0.21 & 0.00 \\
\hline Median & 3.22 & 1.18 & 0.52 & 4.39 \\
\hline Average & 3.32 & 1.33 & 0.54 & 4.47 \\
\hline
\end{tabular}

$0.369 \mathrm{~g} / \mathrm{kg}$-day for consumption of recreationally caught fish is representative of children aged six was used here. Please note that this value will also be protective of adults. In general, site-specific data on fish consumption is prefer- able to default values such as these. Hence, it may be advisable to obtain site-specific fish consumption data for this Superfund site in the future. In this study, the risk estimates for consumption of fish at this Superfund site are based on these default consumption rates.

$\mathrm{HQ}=\frac{C_{\text {fish }} \cdot \mathrm{IR}_{\mathrm{fish}}}{\mathrm{RfD}}$,

where HQ is the hazard quotient, $C_{\text {fish }}$ is the concentration in fish $=228 \mu \mathrm{g} / \mathrm{kg}, \quad \mathrm{IR}_{\text {fish }}$ is the ingestion rate of fish $=0.369 \mathrm{~g} / \mathrm{kg}$-day, $\quad \mathrm{RfD}$ is the reference do$\mathrm{se}=2 \mathrm{E}-05 \mathrm{mg} / \mathrm{kg}$-day.

Substituting the values and converting units as follows yields a hazard quotient value of 4 for $\sum 3 \mathrm{PC}$.

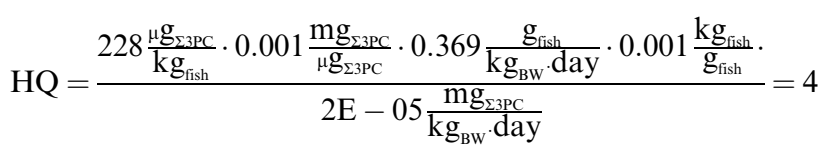

\subsection{Application and development of preliminary remediation goals using the RfD for WT}

In applying the $\mathrm{RfD}$ for $\sum 3 \mathrm{PC}$ for the development of preliminary remediation goals (PRGs) (USEPA, 2004b) or cleanup levels, back calculation is needed to obtain the PRG concentration of WT that corresponds to $\sum 3 \mathrm{PC}$ based on the percentage of $\sum 3 \mathrm{PC}$ in the WT mixture. There has been considerable and continuing debate over the appropriate analytical methods for WT (de Geus et al., 2000). The key message here is that it will likely be necessary to know the concentration of $\sum 3 \mathrm{PC}$ for risk assessment and this concentration needs to be related to the total WT concentration. This may be possible with a range of analytical methods, but the risk assessor should remain cognizant of this possible pitfall of different results with different analytical methods.

The methodology and exposure assumptions used in the Region 9 Table of PRGs were used to develop PRGs for WT based on $\sum 3$ PC. For air, the percentage of $\sum 3 \mathrm{PC}$ in WT was estimated from Bidleman et al. (2004) at $8.8 \%$. For soil, the percentage of $\sum 3 \mathrm{PC}$ in WT was assumed to be $10 \%$; for water, $5 \%$. PRGs for both $\sum 3 \mathrm{PC}$ and WT based on the toxicity of $\sum 3 \mathrm{PC}$ are shown in Table 5. Please note that it is not appropriate to use these WT PRGs as cleanup levels without site-specific determination of the percentage of $\sum 3 \mathrm{PC}$ in WT.

\section{Discussion}

\subsection{Is the CLE representative of WT?}

It should be clear from the few (2-5) congeners that comprise the human body burden versus the many congen- 
ers present in technical toxaphene $(>600)$ that changes in the composition of the material occurs once released in the environment. A multitude of studies indicate that toxaphene in the environment weathers and the resulting mixture consists of a much smaller number of congeners than in the original TT. As discussed, the persistent congeners that make up the human body burden are p-26, p-50, and $\mathrm{p}-62$. However, a larger number of congeners occur in fish and other biota. The persistence of the various congeners is determined by their thermodynamic stabilities and molecular structural energies (Heimstad et al., 2001). Microbial degradation of toxaphene shows specificity for the removal of chlorines in particular positions on the molecule (Ruppe et al., 2003, 2004). In addition, biotic and abiotic transformation of toxaphene results in different mixtures of congeners (Angerhofer et al., 1999).

Table 6 shows the percentage of the three congeners in biota from a variety of sources (Chan et al., 1998; Chan and Yeboah, 2000; Skopp et al., 2002a). The percentage of p-26 ranges from 0.33 to $30 \%, \mathrm{p}-50$ ranges from 0.45 to $25 \%$, and $\mathrm{p}-62$ ranges from 0.33 to $13 \%$. The average percentage of $\sum 3 \mathrm{PC}$ in the mixture is $22 \%$. Table 7 shows the percentages of the three congeners from fish samples obtained at a Superfund site collected in 1997 (Maruya, 2000). The percentage of $\mathrm{p}-26$ ranges from 0.28 to $6 \%$, p50 ranges from 0.41 to $3.4 \%$, and $\mathrm{p}-62$ ranges from 0.21 to $1.21 \%$. The average percentage of $\sum 3 \mathrm{PC}$ in the mixture is $4.5 \%$. The samples shown in Table 6 were obtained from fish obtained at northern latitudes that are generally higher in fat than fish obtained from more temperate climates, such as the samples in Table 7. This effect of latitude was also observed by McHugh et al. (2004). Their higher fat content and larger size may be reasons for the higher percentages of $\sum 3 \mathrm{PC}$ in the coldwater fish.

\subsection{Comparison of toxaphene toxicity criteria}

One can compare the toxicity criteria for $\sum 3 \mathrm{PC}$ with that for TT in terms of fish concentrations. For the TT slope factor, the typical Lifetime Receptor for carcinogenic effects was defined as an individual exposed from age 0 to 30,6 years as a child and 24 years as an adult. Age-specific body weights and fish consumption rates were obtained from USEPA (1997a). For each year from 1 to 30, the fish consumption rate in $\mathrm{g} /$ day was divided by the body weight. These resulting values were averaged over all 30 years to obtain the Lifetime Receptor fish consumption rate (FCR) or $0.194 \mathrm{~g} / \mathrm{kg}$-day (Table 8).

The fish concentration representative of a $1 \mathrm{E}-06$ cancer risk using the TT slope factor in a Lifetime Receptor is $0.011 \mathrm{mg} / \mathrm{kg}$. This calculation was performed iteratively by substituting a range of fish concentrations in Eq. (2) shown below until the risk was equal to $1 \mathrm{E}-06$

Risk $=\mathrm{CSF} \cdot \frac{C_{\text {fish }} \cdot \mathrm{IR}_{\text {fish }} \cdot 0.001 \frac{\mathrm{kg}}{\mathrm{g}} \cdot 30 \mathrm{yr} \cdot 365 \frac{\text { days }}{\mathrm{yr}}}{25550 \frac{\text { days }}{\text { lifetime }}}$
Table 8

Calculation of fish ingestion rate for lifetime receptor

\begin{tabular}{|c|c|c|c|}
\hline Age & $\begin{array}{l}\text { Consumption } \\
\text { (g/day) }\end{array}$ & $\begin{array}{l}\text { Body } \\
\text { weight } \\
(\mathrm{kg})\end{array}$ & $\begin{array}{l}\text { Yearly average } \\
\text { fish ingestion rate } \\
(\mathrm{g} / \mathrm{kg} \text {-day })\end{array}$ \\
\hline 0 & 0 & 9.4 & 0 \\
\hline 1 & 5.63 & 11.8 & 0.477 \\
\hline 2 & 5.63 & 12.9 & 0.436 \\
\hline 3 & 5.63 & 15.1 & 0.373 \\
\hline 4 & 5.63 & 17.1 & 0.329 \\
\hline 5 & 5.63 & 19.4 & 0.290 \\
\hline 6 & 7.94 & 21.7 & 0.366 \\
\hline 7 & 7.94 & 25.5 & 0.311 \\
\hline 8 & 7.94 & 28.1 & 0.283 \\
\hline 9 & 7.94 & 32.7 & 0.243 \\
\hline 10 & 7.94 & 35.6 & 0.223 \\
\hline 11 & 7.27 & 41.5 & 0.175 \\
\hline 12 & 7.27 & 46.9 & 0.155 \\
\hline 13 & 7.27 & 55.1 & 0.132 \\
\hline 14 & 7.27 & 61.1 & 0.119 \\
\hline 15 & 7.27 & 62.8 & 0.116 \\
\hline 16 & 7.27 & 65.8 & 0.110 \\
\hline 17 & 7.27 & 67.5 & 0.108 \\
\hline 18 & 7.27 & 70 & 0.104 \\
\hline 19 & 7.27 & 70 & 0.104 \\
\hline 20 & 7.27 & 70 & 0.104 \\
\hline 21 & 10.2 & 70 & 0.146 \\
\hline 22 & 10.2 & 70 & 0.146 \\
\hline 23 & 10.2 & 70 & 0.146 \\
\hline 24 & 10.2 & 70 & 0.146 \\
\hline 25 & 10.2 & 70 & 0.146 \\
\hline 26 & 10.2 & 70 & 0.146 \\
\hline 27 & 10.2 & 70 & 0.146 \\
\hline 28 & 10.2 & 70 & 0.146 \\
\hline 29 & 10.2 & 70 & 0.146 \\
\hline 30 & 10.2 & 70 & 0.146 \\
\hline Average for years $0-30$ & & & 0.194 \\
\hline
\end{tabular}

where CSF is the cancer slope factor $=1.1 \mathrm{per} \mathrm{mg} / \mathrm{kg}$-day, Risk is the $1 \mathrm{E}-06, C_{\text {fish }}$ is the concentration in fish (solved iteratively), $I_{\mathrm{fish}}$ is the lifetime fish ingestion rate $=0.194 \mathrm{~g} / \mathrm{kg}$-day (Table 8$)$.

The application of the tolerable daily intake (TDI) toxicity criterion developed in (MATT, 2000) or $0.0069 \mathrm{mg} /$ kg-day was performed with Eq. (3). The resulting fish concentration developed corresponding to an HQ of 1 was $35 \mathrm{mg} / \mathrm{kg}$.

Acceptable Conc $_{\mathrm{CLE}}$ in fish $=\frac{\mathrm{TDI}_{\mathrm{CLE}}}{\mathrm{IR}_{\mathrm{fish}} \cdot 0.001 \mathrm{~kg} / \mathrm{g}}$,

where $\mathrm{TDI}_{\mathrm{CLE}}$ is the tolerable daily intake for $\mathrm{CLE}=0.0069 \mathrm{mg} / \mathrm{kg}$-day, $\mathrm{IR}_{\mathrm{fish}}$ is the fish ingestion rate $=0.194 \mathrm{~g} / \mathrm{kg}$-day (Lifetime).

The fish concentration of WT representative of $\sum 3 \mathrm{PC}$ at $22 \%$ of the mixture (Table 6) and at an HQ of 1 for a Lifetime Receptor is $0.45 \mathrm{mg} / \mathrm{kg}$. The fish concentration of WT representative of the $\sum 3 \mathrm{PC}$ at $4.5 \%$ (Table 7) and at an HQ of 1 for a Lifetime Receptor is $2.2 \mathrm{mg} / \mathrm{kg}$. Eqs. (4a) and (4b) shows this calculation. 


$$
\begin{aligned}
& \text { Acceptable Conc } \sum_{\sum 3 \mathrm{PC} \text { in fish }} \\
& =\frac{\mathrm{RfD}_{\sum 3 \mathrm{PC}}}{\mathrm{IR}_{\text {fish }} \cdot 0.001 \mathrm{~kg} / \mathrm{g} \cdot \% \sum 3 \mathrm{PC}}
\end{aligned}
$$

where $\mathrm{RfD}_{\sum 3 \mathrm{PC}}$ is the reference dose for $\sum 3 \mathrm{PC}=2 \mathrm{E}-05 \mathrm{mg} / \mathrm{kg}$-day, $\mathrm{IR}_{\text {fish }}$ is the fish ingestion rate $=0.194 \mathrm{~g} / \mathrm{kg}$-day (Lifetime), and $\% \sum 3 \mathrm{PC}$ is the percentage of $\sum 3 \mathrm{PC}$ in the WT mixture.

Substituting values, one obtains

$$
\begin{aligned}
\text { Acceptable } \text { Conc }_{\text {fish }} & =\frac{2 \mathrm{E}-05 \mathrm{mg} / \mathrm{kg} \text {-day }}{0.194 \mathrm{~g} / \mathrm{kg}-\text { day } \cdot 0.001 \mathrm{~kg} / \mathrm{g} \cdot 22 \%} \\
& =0.45 \mathrm{mg} / \mathrm{kg}
\end{aligned}
$$

\subsection{Toxaphene and human cancers}

Toxaphene has been shown to disrupt GJIC in normal human breast epithelial cells and human cancer cells (Kang et al., 1996; Kao et al., 1995). Because of the high fat content of artic marine mammals, these animals represent a reservoir of WT (e.g., Chan and Yeboah, 2000). The Circumpolar Inuit people consume large quantities of marine mammals and are highly exposed to toxaphene relative to the US population with plasma concentrations of WT up to $4 \mu \mathrm{g} / \mathrm{L}$ (Bjerregaard et al., 2001; Sandanger et al., 2003; Walker et al., 2003; Van Oostdam et al., 2005). The Inuit have approximately twentyfold lower breast cancer rates than comparison populations so clearly this concentration is less than a frank effect level.

This additional information indicates that the toxicity assessment presented here is very likely to be protective of tumor promotion in humans and other endpoints as well. Current human exposure to toxaphene is to WT, not TT and the continued use of the more stringent toxicity assessment for technical toxaphene will result in inaccurate risk/hazard estimates and possibly unnecessary and overly costly cleanups.

\section{References}

Andrews, P., Headrick, K., Pilon, J.C., Bryce, F., Iverson, F., 1996. Capillary GC-ECD and ECNI GCMS characterization of toxaphene residues in primate tissues during a feeding study. Chemosphere 32, 1043-1053.

Angerhofer, D., Kimmel, L., Koske, G., Fingerling, G., Burhenne, J., Parlar, H., 1999. The role of biotic and abiotic degradation processes during the formation of typical toxaphene peak patterns in aquatic biota. Chemosphere 39, 563-568.

Arbour, L., Gilpin, C., Millor-Roy, V., Platt, R., Pekeles, G., Egeland, G.M., Hodgins, S., Eydoux, P., 2004. Heart defects and other malformations in the Inuit in Canada: a baseline study. Int. J. Circumpolar Health 63, 251-266.

Arcaro, K.F., Yang, Y., Vakharia, D.D., Gierthy, J.F., 2000. Toxaphene is antiestrogenic in a human breast-cancer cell assay. J. Toxicol. Environ. Health Part A 59, 197-210.

Arnold, D.L., Bryce, F., Baccanale, C., Hayward, S., Tanner, J.R., MacLellan, E., Dearden, T., Fernie, S., 2001. Toxicological consequences of toxaphene ingestion by cynomolgus (Macaca fascicularis) monkeys. Part 1: pre-mating phase. Food Chem. Toxicol. 39, 467-476.

Bager, Y., Kato, Y., Kenne, K., Warngard, L., 1997. The ability to alter gap junction protein expression outside GST-P positive foci in liver of rats was associated to the tumour promotion potency of different polychlorinated biphenyls. Chem. Biol. Interact. 103, 199-212.

Barnes, D.G., Dourson, M., 1988. Reference dose (RfD): description and use in health risk assessments. Regul. Toxicol. Pharmacol. 8, 471-486.

Barr, J.R., Woolfitt, A.R., Maggio, V.L., Patterson, D.G., 2004. Measurement of toxaphene congeners in pooled human serum collected in three US cities using high-resolution mass spectrometry. Arch. Environ. Contam. Toxicol. 46, 551-556.

Bartos, T., Skaret, M., Cupr, P., et al., 2005. Genotoxic activity of a technical toxaphene mixture and its photodegradation products in SOS genotoxicity tests. Mutation Res. 565, 113-120.

Besselink, H., Nixon, E., McHugh, B., Klungsoyr, J., Brouwer, A., 2000. In vitro and in vivo tumor promoting potency of technical toxaphene, uv-irradiated toxaphene, and biotransformed toxaphene. Organohalogen Compounds 47, 113-116.

Bidleman, T.F., Cussion, S., Jantunen, L.M., 2004. Interlaboratory study of toxaphene analysis in ambient air. Atmos. Environ. 38, 3713-3722.

Biessman, A., Mohammed, A., Slanina, P., 1983. Studies on the tissue deposition and fate of $\left[{ }^{14} \mathrm{C}\right]$ toxaphene in Japanese Quail. Toxicology 28 (1-2), 156-165.

Bjerregaard, P., Dewailly, E., Ayotte, P., Pars, T., Ferron, L., Mulvad, G., 2001. Exposure of Inuit in Greenland to organochlorines through the marine diet. J. Toxicol. Environ. Health 62, 69-81.

Bonefield, E.C., Autrup, H., Hansen, J.C., 1997. Effect of toxaphene on estrogen receptor functions in human breast cancer cells. Carcinogenesis $18,1651-1654$.

Boon, J.P., Sleiderink, H.M., Helle, M.S., Dekker, M., van Schanke, A., Roex, E., Hillebrand, M.T.J., Klamer, H.J.C., Govers, B., Pastor, D., Morse, D., Wester, P.C., de Boer, J., 1998. The use of a microsomal in vitro assay to study phase I biotransformation of chlorobornanes (Toxaphene) in marine mammals and birds. Possible consequences of biotransformation for bioaccumulation and genotoxicity. Comp. Biochem. Physiol. C 121, 385-403.

Bryce, F., Iverson, F., Andrews, P., Barker, M., Cherry, W., Mueller, R., Pulido, O., Hayward, S., Fernie, S., Arnold, D.L., 2001. Effects elicited by toxaphene in cynomolgus monkey (Macaca fascicularis): a pilot study. Food Chem. Toxicol. 29, 1243-1251.

Buranatrevedh, S., 2004. Cancer risk assessment of toxaphene. Ind. Health 42 (3), 321-327.

Calciu, C., Chan, H.M., Kubow, S., 1997. Toxaphene congeners differ from toxaphene mixtures in their dysmorphogenic effects on cultured rat embryos. Toxicology 124, 153-162.

Calciu, C., Kubow, S., Chan, H.M., 2002. Interactive dysmorphogenic effects of toxaphene or toxaphene congeners and hyperglycemia on cultured whole rat embryos during organogenesis. Toxicology 175, 153-165.

Chan, H.M., Berti, P.R., Receveur, O., Kuhnlein, H.V., 1997. Evaluation of the population distribution of dietary contaminant exposure in an arctic population using monte carlo statistics. Environ. Health Perspect. 105 (3), 316-321.

Chan, H.M., Zhu, J., Yeboah, F., 1998. Determination of toxaphene in biological samples using high-resolution GC couples with ion trap MS/ MS. Chemosphere 36, 2135-2148.

Chan, H.M., Yeboah, F., 2000. Total toxaphene and specific congeners in fish from the Yukon, Canada. Chemosphere 41, 507-515.

Chu, I., Secours, V., Villeneuve, D.C., Valli, V.E., Nakamura, A., Colin, D., Clegg, D.J., Arnold, E.P., 1988. Reproduction study of toxaphene in the rat. J. Environ. Sci. Health B 23 (2), 101-126.

Crump, K.S., 1984. An improved procedure for low-dose carcinogenic risk assessment from animal data. J. Environ. Pathol. Toxicol. Oncol. 5, 339-348. 
Epstein, S., Arnold, E., Andrea, J., Bass, W., Bishop, Y., 1972. Detection of chemical mutagens by the dominant lethal assay in the mouse. Toxicol. Appl. Pharmacol. 23, 288-325.

Faustman, E.M., Silbernagel, S.M., Fenske, R.A., Burbacher, T.M., Ponce, R.A., 2000. Mechanisms underlying children's susceptibility to environmental toxicants. Environ. Health Perspect. 108 (Suppl. 1), 1321.

Fitzgerald, D.J., Mesnil, M., Oyamada, M., Tsuda, H., Ito, N., Yamasaki, H., 1989. Changes in gap junction protein (connexin 32) gene expression during rat liver carcinogenesis. J. Cell. Biochem. 41, 97-102.

Gaudette, L.A., Gao, R.N., Freitag, S., Wideman, M., 1993. Cancer incidence by ethnic group in the Northwest Territories. Health Rep. 5, $23-32$.

Gaudette, L.A., Silberberger, C., Altmayer, A., Gao, R.-N., 1996. Trends in breast cancer incidence and mortality. Health Rep. 8 (2), 29-37.

de Geus, H.J., Besselink, H., Brouwer, A., Klungsoyr, J., McHugh, B., Nixon, E., Rimkus, G.G., Wester, P.G., de Boer, J., 1999. Environmental occurrence, analysis, and toxicology of toxaphene compounds. Environ. Health Perspect. 107 (Suppl. 1), 115-144.

de Geus, H.J., Wester, P.G., Schelvis, A., de Boer, J., Brinkman, U.A.T., 2000. Toxaphene: a challenging analytical problem. J. Environ. Monit. 2, 503-511

Gill, U.S., Schwartz, H.M., Wheatley, B., Parlar, H., 1996. Congener specific analysis of toxaphene in serum using ECNI-MS. Chemosphere 33, 1021-1025.

Goodman, J.I., Brusick, D.J., Busey, W.M., Cohen, S.M., Lamb, J.C., Starr, T.B., 2000. Reevaluation of the cancer potency factor of toxaphene: recommendations from a peer review panel. Toxicol. Sci. 55, 3-16.

Heimstad, E.S., Smalas, A.O., Kallenborn, R., 2001. Environmental fate of chlorinated bornanes estimated by theoretical descriptors. Chemosphere 43, 665-674.

Hooper, N.K., Ames, B.N., Saleh, M.A., Casida, J.E., 1979. Toxaphene, a complex mixture of polychlorinated terpenes and a major insecticide, is mutagenic. Science 205, 591-593.

Ito, N., Tatematsu, M., Hasegawa, R., Tsuda, N., 1989. Medium-term bioassay system for detection of carcinogens and modifiers of hepatocarcinogenesis utilizing the GST-P positive liver cell focus as an endpoint marker. Toxicol. Pathol. 17, 630-641.

Kang, K.-S., Wilson, M.R., Hayashi, T., Chang, C.-C., Trosko, J.E., 1996. Inhibition of gap junctional intercellular communication in normal human breast epithelial cells after treatment with pesticides, $\mathrm{PCBs}$, and PBBs, alone or in mixture. Environ. Health Perspect. 104, 192-201.

Kao, C.-Y., Nomata, K., Oakley, C.S., Welsch, C.W., Chang, C.-C., 1995. Two types of normal human breast epithelial cells derived from reduction mammoplasty: phenotypic characterisation and response to SV40 transfection. Carcinogenesis 16, 531-538.

Kolaja, K.L., Engelken, D.T., Klaassen, C.D., 2000. Inhibition of gapjunctional intercellualar communication in intact rat liver by nongenotoxic hepatocarcinogens. Toxicology 146, 15-22.

Krutovskikh, V.A., Oyamda, M., Yamaski, H., 1991. Sequential changes of gap junctional intercellular communications during multistage rat liver carcinogenesis: direct measurements of communication in vivo. Carcinogenesis 112, 1701-1706.

Landrigan, P.J., Sonawane, B., Mattison, D., McCally, M., Garg, A., 2002. Chemical contaminants in breast milk and their impacts on children's health: an overview. Environ. Health Perspect. 110 (6), A313-A315.

Macaulay, A., Orr, P., Macdonald, S., Elliott, L., Brown, R., Durcan, A., Martin, B., 2004. Mortality in the Kivalliq Region of Nunavut, 19871996. Int. J. Circumpolar Health 63, 80-85.

Maruya, K., 2000. Analysis of Toxaphene Residues in Fin- and Shellfish from Terry/Dupree Creek, Glynn County, GA, submitted to Dr. Randall Manning, Georgia EPD.

MATT, 2000. Final Report, Investigation into the Monitoring, Analysis and Toxicity of Toxaphene in Marine Foodstuffs FAIR CT PL.96.3131.
McHugh, B., McGovern, E., Nixon, E., Klungsoyr, J., Rimkus, G.G., Leonards, P.E., deBoer, J., 2004. Baseline survey of concentrations of toxaphene congeners in fish from European waters. J. Environ. Monit. 6, 665-672.

McKarns, S.C., Doolittle, D.J., 1982. Limitations of the scrape-loading/ dye transfer technique to quantify inhibition of gap junctional intercellular communication. Cell Biol. Toxicol. 8, 89-103.

Miller, A.B., Gaudette, L.A., 1996. Breast cancer in circumpolar Inuit 1969-1988. Acta Oncol 35, 577-580.

Mohammed, A., Andersson, O., Biessman, A., Slanina, P., 1983. Fate and specific tissue retention of toxaphene in mice. Arch. Toxicol. 54 (4), 311-321.

Mortelsman, K., Haworth, S., Lawlor, T., Speck, W., Tainer, B., Zeiger, E., 1986. Salmonella mutagenicity tests II. Results from the testing of 270 chemicals. Environ. Mutagen. 8 (Suppl. 7), 1-119.

National Toxicology Program (NTP), 1979. Bioassay of Toxaphene for Possible Carcinogenicity.

Nielsen, N.H., Storm, H.H., Gaudette, L.A., Lanier, A.P., 1996. Cancer in circumpolar Inuit 1969-1988. A summary. Acta Oncol. 35, 621-628.

OEHHA (CAL-EPA), 2003. Public health goal document for toxaphene in drinking water. $<$ http://www.oehha.ca.gov/water/phg/pdf/Ph4Toxap92603.pdf/>.

Olson, K.L., Matusumura, F., Bousli, G.M., 1980. Behavioral effects of juvenile rats from perinatal exposure to low levels of toxaphene and its toxic components, toxicant A and toxicant B. Arch. Environ. Contam. Toxicol. 9, 247-257.

Polder, A., Odland, J.O., Tkachev, A., Foreid, S., Savinova, T.N., Skaare, J.U., 2003. Geographic variation of chlorinated pesticides, toxaphenes and PCBs in human milk from sub-arctic and arctic locations in Russia. Sci. Tot. Environ. 306, 179-195.

Pollock, G.A., Hillstrand, R., 1982. The elimination, distribution, and metabolism of ${ }^{14} \mathrm{C}$-toxaphene in the pregnant rat. J. Environ. Sci. Health B 17 (6), 635-648.

Pollock, G.A., Kilgore, W., 1980. Excretion and storage of $\left[{ }^{14} \mathrm{C}\right]$ toxaphene and two isolated $\left[{ }^{14} \mathrm{C}\right]$ toxaphene fractions. J. Toxicol. Environ. Health 6 (1), 127-140.

Receveur, O., Kassi, N., Chan, H.M., Berti, P.R., Kuhnlein, H.V., 1998. Yukon first nations' assessment dietary benefit/risk. Centre for Indigenous Peoples' Nutrition and Environment, Macdonald Campus of McGill University. <http://www.contaminants.ca/done/dietaryRiskStudy//>.

Ruppe, S., Neumann, A., Vetter, W., 2003. Anaerobic transformation of compounds of technical toxaphene. 1. Regiospecific reaction of chlorobornanes with geminal chlorine atoms. Environ. Toxicol. Chem. 22, 2614-2621.

Ruppe, S., Neumann, A., Braekevelt, E., Tomy, G.T., Stern, G.A., Maruya, K.A., Vetter, W., 2004. Anaerobic transformation of compounds of technical toxaphene. 2. Fate of compounds lacking geminal chlorine atoms. Environ. Toxicol. Chem. 23, 591-598.

Samosh, L.V., 1974. Chromosomal aberrations and the character of satellite associations following accidental exposure of the human body to polychlorocamphene. Tsitol. Genet. 8, 24-27.

Sandanger, T.M., Odland, J.O., Tkachev, A., Burkow, I.C., 2003. Persistent Organic Pollutants in plasma of delivering women in Arkhangelsk. Sci. Tot. Environ. 306, 171-178.

Skopp, S., Oehme, M., Chu, F.L., Yeboah, F., Chan, H.M., $2002 \mathrm{a}$. Analysis of "Total Toxaphene" and selected single congeners in biota by ion trap HRGC-EI-MS/MS using congener-optimized parent ion dissociations. Environ. Sci. Technol. 36, 2729-2735.

Skopp, S., Oehme, M., Furst, P., 2002b. Enantiomer ratios, patterns and levels of toxaphene congeners in human milk from Germany. J. Environ. Monit. 4, 389-394.

Sobti, R.C., Krishan, A., Davies, J., 1983. Cytogenic and cytogenetic effect of agricultural chemicals on human lymphoid cells in vitro. II. Organochlorine pesticides. Arch. Toxicol. 52, 221-231.

Spencer, A.N., Satterlie, R.A., 1980. Electrical and dye coupling in an identified group of neurons in a coelenterate. J. Neurobiol. 11, 13-19. 
Steinberg, M., Kinoshita, F.K., Ballantyne, M., 1998. Mutagenicity studies with toxaphene congeners. Organohalogen Compounds 35, 243-246.

Steinel, H.H., Arlauskas, A., Baker, R.S., 1990. SCE induction and cell cycle delay by toxaphene. Mutat. Res. 230, 29-33.

Stelzer, A., Chan, H.M., 1999. The relative estrogenic activity of technical toxaphene mixture and two individual congeners. Toxicology 138, 6980.

Tryphonas, H., Bryce, F., Huang, J., LaCrois, F., Hodgen, M., Ladouceur, D.T., Hayward, S., 2000. Effects of toxaphene on the immune system of cynomolgus (Macaca fascicularis) monkeys. A pilot study. Food Chem. Toxicol. 38, 25-33.

Tryphonas, H., Arnold, D.L., Bryce, F., Huang, J., Hodgen, M., Ladouceur, D.T., Fernie, S., Lepage-Parenteau, M., Hayward, S., 2001. Effects of toxaphene on the immune system of cynomolgus (Macaca fascicularis) monkeys. Food Chem. Toxicol. 39, 947-958.

USEPA, 1978. Occupational exposure to toxaphene. A Final Report by the Epidemiological Studies Program. OPPTS.

USEPA, 1997a. Exposure factors handbook. <http://cfpub.epa.gov/ncea/ $\mathrm{cfm} /$ recordisplay.cfm?deid $=12464 />$.

USEPA, 1997b. Summary of the US EPA Colloquia on a Framework for Human Health Risk Assessment, vol. 1, 1997. Washington, DC, EPA/ 600/R-99/001.

USEPA, 1998. Summary of the US EPA Colloquium on a Framework for Human Health Risk Assessment, vol. 2, 1998. Risk Assessment Forum, Washington, DC.
USEPA, 2000. Benchmark Dose Technical Guidance Document, EPA 630/R01/001. $\quad<$ http://cfpub.epa.gov/ncea/cfm/recordisplay.cfm?deid $=20871 />$.

USEPA, 2004a. PROUCL Software v. 3.0. < http://www.epa.gov/nerlesd1/tsc/software.htm/>.

USEPA, 2004b. Preliminary Remediation Goals. <http://www.epa.gov/ region09/waste/sfund/prg/index.html/>.

USEPA, 2005. Guidelines for Carcinogen Risk Assessment, EPA/630/P03/001F. <http://www.epa.gov/ncea/>.

Van Oostdam, J., Donaldson, S.G., Feeley, M., Arnold, D., Ayotte, P., Bondy, G., Chan, L., Dewaily, E., Furgal, C.M., Kuhnlein, H., Loring, E., Muckle, G., Myles, E., Receveur, O., Tracy, B., Gill, U., Kalhok, S., 2005. Human health implications of environmental contaminants in Arctic Canada: A review. Sci Total Environ., 351352:165-246 Epub.

Walker, J.B., Seddon, L., McMullen, E., et al., 2003. Organochlorine levels in maternal and umbilical cord blood plasma in Arctic Canada. Sci. Tot. Environ. 302, 27-52.

Yamasaki, H., 1990. Gap junctional intercellular communication and carcinogenesis. Carcinogenesis 11, 1051-1058.

Young, J.C., Freeman, A.D., 2001. Bioavailability and mutagenicity of toxaphene after aging in anoxic soil environments. Report of work conducted under agreement 9C-R570 NASA with USEPA's ORD.

Young, J.C., Freeman, A.D., 2004. Comparing the mutagenicity of toxaphene after aging in anoxic soils and accumulating in fish. Report of work conducted under agreement 1C-R234 NASA with USEPA's ORD. 